\title{
ASPEK HUKUM \\ TRANSFORMASI MANAJEMEN PEMERINTAHAN KOTA BANDUNG TAHUN 2013-2016
}

\author{
Nandang Alamsah Deliarnoor \\ Departemen Ilmu Pemerintahan \\ Fakultas Ilmu Sosial Ilmu Politik Universitas Padjadjaran \\ e-mail: nandangalamsah@gmail.com
}

\begin{abstract}
ABSTRAK
Pemerintahan Kota Bandung pasca pergantian walikota pada tahun 2013 telah terjadi adanya reframing walaupun tidak disertai restructuring. Dalam hal revitalization dan renewal ada sedikit dilakukan namun tidak dibarengi dengan perubahan regulasi yang memadai contohnya tentang konsep Bandung Juara yang merupakan suatu renewal dalam menyemangati aparat untuk giat meraih prestasi dalam berbagai bidang sehingga menjadikan Bandung juara. Sebaiknya adanya transformasi manajemen pemerintahan ini dibarengi secara simultan dengan memberikan landasan hukum formal setingkat Peraturan Daerah dan didukung kekuatan politik di lembaga DPRD Kota Bandung. Hal inilah yang terungkap saat wawancara dengan pihak DPRD Kota Bandung yang menunggu pihak Pemerintah Kota in casu Walikota untuk merapat ke DPRD membicarakan langkah konkrit dalam mewujudkan reframing baru di Kota Bandung.
\end{abstract}

Kata kunci : reframing, restruturing, revitalization, renewal.

\section{ABSTRACT}

After a change of Mayor in 2013 there has been a reframing in Bandung city administration although it has not been accompanied by a restructuring. In case of revitalization and renewal, few things have been done but they have not been accompanied by sufficient changes in regulations, for example the concept of Bandung Juara/Bandung Champion which is a renewal in encouraging the officers to keenly accomplish their objectives in all fields to make Bandung a champion. The transformation of administration management should be simultaneously accompanied by giving a formal legal basis equivalent to a Regional Regulation that is supported by political powers of Regional People's Representatives Assembly in Bandung. This circumstance was revealed during the interview with Regional People's Representatives Assembly in Bandung who waits for the City Government in casu Mayor to discuss concrete measures in realizing new reframing in Bandung.

Key Words: reframing, restruturing, revitalization, renewal.

\section{PENDAHULUAN}

Tulisan ini mengetengahkan hasil penelitian penulis tentang transformasi manajemen pemerintahan yang terjadi di
Pemerintah Kota Bandung dari Tahun 2013 sampai 2016 yang dilihat dari kacamata hukum atau analisa hukum. Penulis hanya salah satu saja anggota dari Tim Academic 
Leadership Grand (ALG) Prof. Dr. Drs. H. Samugyo Ibnu Redjo, M.A., yang secara khusus menggunakan pendekatan ilmu hukum untuk menganalisis transformasi manajemen pemerintahan di Pemerintah Kota Bandung. Rekanrekan anggota ALG yang lain ada yang melihatnya dari kacamata Ilmu Administrasi Publik, Politik, Sosiologi atau Etika Pemerintahan.

Metode yang digunakan pada penelitian ini menggunakan pendekatan yuridis normatif atau penelitian hukum normatif (Soerjono Soekanto dan Sri Mamudji, 1995). Penelitian yuridis normatif adalah penelitian hukum yang meletakkan hukum sebagai sebuah bangunan sistem norma. Sistem norma yang dimaksud adalah mengenai asas-asas, norma, kaidah dari peraturan perundang-undangan, serta doktrin atau ajaran.

Teori Transfomasi Manajemen Pemerintahan yang digunakan berupa inovasi-inovasi dalam transformasi yang meliputi reframing, restructuring, revitalization dan renewal yang disampaikan Gouillart dan Kelly (1995: 6). Sedangkan teori hukum yang akan dijadikan batu uji terhadap adanya transformasi manajemen pemerintahan ini adalah teori Lawrence M. Friedman tentang legal substance, legal structur dan legal cultur (2009).

Beberapa pertanyaan penelitian yang muncul sebelum melihat bagaimana kaitan aspek hukum dalam transformasi pemerintahan adalah apakah sudah terjadi reframing pasca pergantian Walikota tahun 2013? Demikian pula dengan restructuring, revitalization dan renewal, apakah Walikota baru telah melakukannya dalam memanajemen pemerintah Kota Bandung sejak dilantik sampai tahun 2016 ini.

\section{PEMBAHASAN}

a. Reframing.

Menurut Gouillart dan Kelly (1995: 7), reframing is the shifting of the company's conception of what it is and what it can achieve. It adresses the corporate mind. Corporate often get stuck in a certain way of thinking, and lose the ability to develop fresh mental models of what they are and what they could become. Reframing opens the corporate mind and infuses it with new visions and new resolve (Terjemahan bebasnya: bahwa reframing adalah pergeseran konsep perusahaan mengenai apa perusahaan tersebut dan apa yang dapat diraih oleh perusahaan itu. Reframing membahas tentang fikiran perusahaan. Perusahaan seringkali terjebak dalam pola fikir tertentu, dan kehilangan kemampuan untuk mengembangkan model mental baru mengenai jati diri mereka dan apa yang mereka capai. Reframing membuka pikiran perusahaan dan memasukan visi-visi baru dan ketetapan baru).

Berdasarkan hasil wawancara dengan Kepala Bagian Hukum Pemerintah Kota Bandung, Pejabat pada Dinas KUKM dan Perindag, serta salah 
seorang Pimpinan DPRD Kota Bandung diperoleh informasi yang saling mendukung tentang apakah telah terjadi reframing transformasi pemerintahan di Kota Bandung khususnya dari sudut pandang hukum. Dasar hukum visi dan misi pemerintah kota Bandung adalah Peraturan Daerah Kota Bandung Nomor 03 Tahun 2014 tentang Rencana Pembangunan Jangka Menengah Daerah Tahun 2013-2018. Dalam Perda tersebut disebutkan bahwa visi Kepala Daerah Tahun 2013-2018 yaitu Terwujudnya Kota Bandung Yang Unggul, Nyaman dan Sejahtera, sejalan dan selaras dengan Visi Daerah yaitu "Kota Bandung Yang Bermartabat'. Artinya telah ada penambahan visi dari visi daerah sebelumnya, sehingga dapat dikatakan telah ada reframing dengan pergantian Walikota Bandung pada tahun 2013 dari Dada Rosada kepada Ridwan Kamil.

Konsep visi yang merupakan reframing baru itu adalah konsep unggul, nyaman, dan sejahtera. Unggul yaitu menjadi yang terbaik dan terdepan serta contoh bagi daerah lain dalam upaya terobosan perubahan bagi kenyamanan dan kesejahteraan warga Kota Bandung. Nyaman yaitu terciptanya suatu kondisi dimana kualitas lingkungan terpelihara dengan baik, serta dapat memberikan kesegaran dan kesejukan bagi penghuninya. Kota yang nyaman dimana kebutuhan dasar manusia seperti tanah, air dan udara terpenuhi dengan baik sehingga nyaman untuk ditinggali. Sejahtera yaitu mengarahkan semua pembangunan kota pada pemenuhan kebutuhan lahir dan batin warganya, agar manusia dapat memfungsikan diri sebagai hamba dan wakil Tuhan di bumi.

Strategi pemerintahan yang digunakan untuk mencapai visi misi tersebut adalah:

1. Seluruh SKPD di lingkungan Pemerintah Kota Bandung, masyarakat, serta dunia usaha berkewajiban melaksanakan program dan kegiatan yang telah ditetapkan dalam RKPD Tahun secara sinergis dan terintegrasi

2. Pemerintah Kota Bandung berkewajiban menjamin konsistensi antar dokumen perencanaan dan penganggaran. Sebagai pedoman dalam penyusunan APBD Kota Bandung Tahun, RKPD Kota Bandung dijabarkan lebih lanjut dalam dokumen Kebijakan Umum Anggaran Pendapatan dan Belanja Daerah (KUA - APBD) dan Plafon Prioritas Anggaran Sementara (PPAS).

3. Dalam rangka sinkronisasi dan sinergitas pelaksanaan program dan kegiatan pembangunan, yang pendanaannya bersumber dari APBD Kota, APBD Provinsi, APBN/BLN/PHLN dan sumbersumber lainnya yang sah, maka setiap SKPD harus menyusun dan membuat Renja SKPD, sebagai dasar pelaksanaan rencana kegiatan.

4. Pemerintah Kota Bandung memantau dan mengevaluasi pelaksanaan tahapan rencana pembangunan. 
5. Menjaga efisiensi dan efektivitas pelaksana program, yaitu setiap Kepala SKPD melakukan pengendalian pelaksanaan rencana pembangunan/kegiatan melalui upaya koreksi dan melaporkannya secara berkala 3 (tiga) bulan kepada Walikota melalui Kepala Bappeda.

Program prioritas pembangunan Kota Bandung yaitu program yang berorientasi pada pemenuhan hak-hak dasar masyarakat dan pencapaian keadilan yang berkelanjutan sebagai penjabaran dari RPJMD pada tahun yang direncanakan. Program prioritas ini disusun berdasarkan evaluasi pembangunan tahunan, kedudukan tahun rencana, dan capaian kinerja yang direncanakan dalam RPJMD, serta aspirasi masyarakat yang disepakati dalam Musrenbang Tahunan.

Program prioritas tersebut dicakup dalam Bandung Sehat, Bandung Resik, Bandung Nyaman, dan Bandung Sejahtera. Program prioritas ini telah dilengkapi dengan rencana aksi sebagaimana dituangkan dalam Instruksi Walikota Bandung Nomor 002 Tahun 2013 tanggal 20 September 2013 tentang Rencana Aksi Menuju Bandung Juara. Pencapaian program prioritas melalui implementasi 335 (tiga ratus tiga puluh lima) kegiatan aksi yang diharapkan dapat mewujudkan Bandung Juara atau Unggul sekaligus Bandung yang Nyaman dan Sejahtera. Perubahan global adalah perubahan yang mendunia, dan akan yang banyak mempengaruhi kondisi lokal (Kota Bandung) itu sendiri. Salah satu bentuknya yaitu pergeseran pola siklikal ekonomi dunia yang menimbulkan ketidakpastian, sehingga terjadi peralihan lanskap ekonmi dunia yang ditandai pertumbuhan ekonomi negara emerging market, adanya tren penurunan harga.

Pemerintah Kota Bandung dalam menghadapi perubahan global di atas, sehubungan dengan naiknya kemiskinan, dan pengangguran maka akan diatasi dengan program pengentasan kemiskinan dan penciptaan lapangan kerja, peningkatan produksi pangan melalui perbaikan melalui intensifikasi, pengembangan sumber energi alternatif, kemudian peningkatan daya saing produk Kota Bandung, pemacuan inovasi untuk pembangunan, penciptaan keterkaitan industri pengolahan dengan sumber daya lokal.

Kemudian visi misi Dinas KUKM\&Perindag menitikberatkan pada upaya peningkatan kompetensi pelaku koperasi, UKM, industri, dan perdagangan agar mampu meningkatkan daya saing dalam rangka menghadapi ekonomi global ASEAN. Dasar hukumnya ada di Renstra bab awal. Strategi pemerintahan yang digunakan untuk mencapai visi misi ini disesuaikan dengan kewenangan pemerintah kota yang terdiri dari 2: regulasi dan fasilitasi. Regulasi menerbitkan perda dan perwal yang menciptakan 
iklim ekonomi yang kondusif dan berpihak pada rakyat kecil. Fasilitasi yaitu subsidi, perizinan, bimtek, sosialisasi, pameran, aplikasi IT, dan lain-lain.

Tujuan pembangunan

KUKM\&Perindag Kota Bandung adalah untuk menciptakan koperasi, UKM, industri, dan perdagangan yang berdaya saing demi perekonomian yang kokoh dan berkeadilan. Prioritas pembangunan KUKM\&Perindag di Dinas adalah penciptaan daya saing, lapangan kerja. Untuk itu, SDM kami fasilitasi. Namun, secara internal kami juga perlu membangun pola pikir PNS di dalamnya berubah sehingga tata kelola organisasinya bisa baik.

Dalam menghadapi perubahan global di Kota Bandung Dinas KUKM \& Perindag dalam menghadapi perubahan masa depan di semua bidang, misalnya Masyarakat Ekonomi ASEAN dengan kita antisipasi dengan visi meningkatkan daya saing agar tercipta perekonomian yang kokoh. Menciptakan regulasi yang punya keberpihakan kepada rakyat kecil dan menciptakan iklim perekonomian yang baik; Penyederhanaan perizinan dan public service lainnya; Penciptaan wirausaha baru; Penciptaan lapangan pekerjaan; Dan kendalikan inflasi.

Berdasarkan uraian di atas dapat disimpulkan telah terjadinya reframing terhadap visi dan misi kota bandung. Ridwan Kamil sebagai Walikota telah menambahkan konsep unggul, nyaman dan sejahtera serta konsep Bandung Juara yang menurut Wakil Ketua DPRD Kota Bandung khusus untuk Bandung Juara ini hanya penyemangat tidak ada dokumen formalnya. Hal ini yang menyebabkan salah satu kelemahan terhadap reframing yang telah dilakukan, sebaiknya walikota mendekat ke DPRD untuk menciptakan regulasi-regulasi lanjutan sebagai tindak lanjut adanya reframing visi dan misi Kota Bandung. Sebagai contoh regulasi dalam rangka mewujudkan Bandung Juara.

\section{b. Restructuring}

Menurut Gouillart dan Kelly (1995: 7), Restructuring is a girding of the corporate loins, getting it to achieve a competitive level of performance. It deals with the body of the corporation, and competitiveness-the need to be lean and fit-is the primary consideration. Restructuring is the domain where payoffs are fastest and cultural difficulties are greatest, often making layoffs and the anxieties associated with them an unavoidable side effect.( Restructuring diibaratkan seperti perusahaan yang mengencangkan ikat pinggang, memacunya untuk mencapai level kinerja yang kompetitip. Restructuring berurusan dengan badan perusahaan, dan tingkat daya saing-kebutuhan agar perusahaan ramping struktur dan sehat merupakan pertimbangan yang utama. Restructuring merupakan 
wilayah dimana pemberian pesanggon terjadi paling cepat dan kesulitan budaya dirasakan paling hebat, sehingga seringkali membuat PHK dan kekhawatiran yang berkaitan dengan PHK tersebut tidak dapat dihindari).

Penerapannya dalam wawancara dengan Kepala Bagian Hukum Pemerintah Kota Bandung, Pejabat pada Dinas KUKM dan Perindag, serta salah seorang Pimpinan DPRD Kota Bandung diperoleh informasi bahwa walaupun telah terjadi adanya reframing terhadap visi dan misi Kota Bandung namun tidak disertai adanya restructuring atau penataan kembali lembaga-lembaga yang ada di Kota Bandung. Hal ini tentu patut disayangkan sebab motor untuk menggerakkan ide-ide itu agar terwujud dalam kenyataan adalah adanya organisasi atau lembaga.

Kota menganggap keberadaan kelembagaan yang ada di lingkungan Pemerintah Kota Bandung sudah cukup memadai untuk dapat melaksanakan seluruh kewenangan dan urusan yang menjadi urusan dan kewenangan Pemerintah Kota Bandung. Demikian pula keberadaan jabatan yang ada di Kota Bandung sudah cukup memenuhi standar yang ditetapkan dalam Peraturan Pemerintah No. 41 Tahun 2007 tentang Organisasi Perangkat Daerah, sehingga menurut Bagian Hukum tidak perlu ada jabatan baru. Hal ini berbeda dengan pendapat peneliti bahwa setiap perubahan visi dan misi mesti juga dipikirkan untuk adanya restructuring untuk mengimbangi perubahan dalam reframing tersebut.

Menarik pendapat dari Dinas UKM \& Perindag terhadap pertanyaan: bagaimana pendapat Ibu, tentang kelembagaan yang ada di Kota Bandung, baik itu keberadaan Dinas dan atau keberadaan lembaga lainya? Apakah masih ada dinas atau lembaga yang kurang sehingga perlu ada lembaga baru? Serta seberapa penting keberadaan dinas yang Bapak/Ibu pimpin? Jawabannya adalah Menterinya saja terpisah ada tiga, ada urusan Koperasi, UKM, industri dan dagang di provinsi ada dua. Sementara di Kota Bandung disatukan berarti sangat luas kerjanya. Berdasarkan jawaban ini tersirat adanya keinginan untuk mengembangkan lembaga eksisting namun tidak terwujud.

Ketika ditanya tentang bagaimana keberadaan jabatanjabatan yang ada di Dinas KUKM \& Perindag? Apa perlu ada jabatan baru, atau ada yang dihapuskan? Jawabannya Orpad tidak bisa semena-mena. Ada analisis dari bagian organisasi, analisis jabatan. Bidang di sini kurang spesifik, butuh wadah tapi tidak bisa karena kami hanya melaksanakan. Satu kasi terlalu padat. Ketika Bagian Hukum Kota ditanya juga tentang perlu tidaknya dalam esolonisasi jabatanjabatan? Apa alasannya kalau perlu atau tidak perlu? Eselonisasi untuk jabatan masih diperlukan karena sesuai dengan ketentuan peraturan perundang-undangan kepegawaian. Hal tersebut agar tingkatan jabatan 
dihargai, sesuai dengan kompetensinya.

Mengenai kejelasan tentang tupoksi lembaga, tantangan dan hambatan atau kelebihan dan kekurangan pembagian dalam lembaga? Bagian Hukum menjawab bahwa tufoksi lembaga sudah jelas tercantum dalam Peraturan Walikota Bandung Nomor 192 Tahun 2011 tentang Uraian Tugas Pokok, Fungsi, Uraian Tugas dan Tata Kerja Satuan Organisasi Sekretariat Daerah Kota Bandung. Nampaknya selama ini tidak ada tantangan begitu juga hambatan untuk Bagian Hukum dan HAM, hanya kekurangannya dalam pelaksanaannya, seharusnya pelaksanaan Kadarkum oleh Sub Bagian Evaluasi dan Dokumentasi Hukum, namun saat ini Kadarkum dilaksanakan oleh Sub Bagian Bantuan Hukum.

Selanjutnya mengenai pemahaman tentang struktur yang ada dalam pemerintahan. Bagian Hukum menjelaskan bahwa Struktur Pemerintahan Indonesia berdasarkan Urutan Teratas dan Terbawah, Indonesia merupakan Negara yang menganut sistem pemerintahan presidensial, dan kemudian hal yang paling berpengaruh dalam birokrasi Indonesia, tentu saja struktur Pemerintahan Indonesia. Struktur pemerintahan ini akan mempengaruhi terbentuknya serangkaian institusi politik untuk menjalankan lajunya pemerintahan sebuah Negara. Dengan demikian, dengan bentuk pemerintahan republik, pemerintahan Indonesia dikepalai oleh presiden dibantu dengan menteri-menteri yang tergabung dalam satu kesatuan kabinet. Para menteri ini nantinya akan memimpin kementerian tertentu. Dengan sistem dan bentuk pemerintahan seperti yang disebutkan di atas, Presiden tidak bertanggung jawab terhadap parlemen, namun para menteri bertanggung jawab terhadap Presiden secara langsung.

Pada dasarnya, sistem Pemerintahan Negara Indonesia terbagi menjadi pemerintahan pusat dan daerah. Hal tersebut tentu mempengaruhi bagaimana struktur Pemerintahan Indonesia. Pemerintahan pusat adalah pemerintahan yang memiliki kewenangan untuk menjalankan suatu sistem untuk menjalankan suatu Negara secara keseluruhan. Dengan demikian, kewenangan pemerintah pusat mencakup kebijakan dalam dan luar negeri, pertahanan dan keamanan Negara, peradilan, moneter dan fiskal, keagamaan, perekonomian Negara, serta kewenangan lainnya seperti perencanaan dan pembangunan nasional dalam skala makro. Sementara itu, pemerintah daerah memiliki kewenangan untuk tingkat daerah yang menjadi penghubung pemerintah pusat dengan masyarakat. Selanjutnya tentang apa saja yang termasuk organisasi masyarakat yang ikut serta berpengaruh terhadap penyelenggaraan pemerintahan Kota Bandung? Menurut Bagian Hukum 
Kota Bandung, Organisasi yang berpengaruh terhadap penyelenggaraan pemerintahan yaitu organisasi penekan (pressure group). Namun demikian hal itu kecil sekali.

Adakah kekuatan politik lain yang berpengaruh terhadap penyelenggaraan pemerintahan Kota Bandung? Menurut Bagian Hukum kekuatan politik yang dapat menekan hanya kekuatan politik yang terlembagakan dalam DPRD.Apakah selama ini ada tumpang tindih kewenangan antar lembaga-lembaga yang ada di Kota Bandung? Apabila dipresentasekan kemungkinan adanya tumpang tindih kewenangan antar lembaga itu sangat kecil. Tapi itu mungkin saja ada karena penyusun kelembagaan adalah produk manusia yang tidak luput dari ketidaksempurnaan. Biasanya yang dapat terjadi kondisi tumpang tindih yaitu menyangkut lembaga perizinan. Apakah lembaga-lembaga tersebut perlu digabung/dihapus/ditambah? Apakah alasannya? Pemerintah Kota Bandung saat ini dalam membuat lembaga selalu berpedoman dan mengikuti ketentuan peraturan perundang-undangan tentang Organisasi Perangkat Daerah sebagaimana tertuang dalam Peraturan Pemerintah Nomor 41 Tahun 2007 tentang Organisasi Perangkat Daerah. Dengan demikian organisasi yang ada saat ini apakah perlu digabung atau ditambah tergantung kepada aturan pedoman yang berlaku. Mengingat Peraturan Pemerintah Nomor 41 Tahun 2007 tentang Organisasi Perangkat Daerah akan diganti seiring dengan terbitnya Undang-Undang Nomor 23 Tahun 2014 tentang Pemerintahan Daerah, maka Pemerintah Kota Bandung akan menunggu Peraturan Pemerintah penggantinya.

Apakah perlu ada privatisasi dalam penyelenggaraan pemerintahan? Tidak perlu ada privatisasi dalam penyelenggaraan pemerintahan. Apakah tupoksi Dinas KUKM \& Perindag sudah jelas? Tidak tumpang tindih dengan lembaga lainnya? Apakah tantangan dan hambatan dalam menjalankan tupoksi tersebut? Ada irisan kelembagaan koperasi dengan PUK (pengembangan koperasi) tetapi tidak kami permasalahkan. Justru orangnya yang belum bisa menerjemahkan tupoksi dalam bentuk pekerjaan yang nyata. Ketidaksesuaian kompetensi dengan bidang pekerjaan menjadi penghambat. Tantangannya ada dalam perubahan mindset birokrat.

Bagaimana pendapat Bapak tentang struktur yang ada di Dinas ini? Cukup tidak cukup, kami menununggu saja dari Pusat. Menurut Bapak, apa saja yang termasuk organisasi masyarakat yang ikut serta berpengaruh terhadap penyelenggaraan pembangunan KUKM \& Perindag di Dinas ini? Komunitas koperasi, APRINDO, banyak sekali LSM di bidang KUKM \& Perindag yang ikut bersama kami. Terhadap pertanyaan, adakah kekuatan politik lain yang berpengaruh

terhadap 
penyelenggaraan KUKM \& Perindag di wilayah kerja Dinas ini? Mohon disebutkan satu persatu terutama kebijakan pembangunan kesehatan apa saja yang dipengaruhi oleh kekuatan politik lainnya. Jawabannya tidak ada..netral. Selanjutnya bagaimana menurut pendapat Bapak, apakah selama ini ada tumpang tindih kewenangan antara Dinas KUKM \& Perindag dengan lembaga lain? Jawabnya ada, sebetulnya seperti istilah UKM dan IKM ada irisan, tapi tidak begitu dipermasalahkan. Bagaimanapun dinas ini terdiri dari beberapa bidang, luas, sehingga ada beberapa irisan dengan yang lain. Tapi, sejauh ini, kita jalan masing-masing, tidak menjadi masalah yang harus diributkan. Apa perlu diprivatisasi penyelenggaraan pembangunan KUKM \& Perindag oleh Dinas? Sebetulnya dinas ada di zona nyaman. Maka dari itu, ke depan regulasi posisi dinas lebih pada public services. Sisanya, kegiatan KUKM \& Perindag bisa lebih aktif secara swasta supaya lebih berkembang.

\section{c. Revitalitation.}

Menurut Gouillart dan Kelly (1995: 7), Revitalization is about igniting growth by linking the corporate body to the environment. Everybody wants to grow, but the sources of growth pften are elusive, making the process of achieving growth more challenging and protracted than restructuring. Of all the four $R$ 's, revitalization is the single greatest factor that clearly distinguishes transformation from mere downsizing. (Revitalition berhubungan dengan memacu pertumbuhan dengan mengaitkan badan perusahaan ke lingkungan. Setiap orang berkeinginan untuk tumbuh, namun sumber pertumbuhan seringkali sukar dipahami, sehingga membuat proses pencapaian pertumbuhan lebih menantang dan berkepanjangan dibandingkang restructuring. Dari ke empat $\mathrm{R}$, revitalizazion merupakan faktor tunggal terbesar yang secara jelas membedakan transformasi dari sekedar perampingan perusahaan).

Diterapkan dalam pemahaman responden tentang potensi alam, potensi SDM, dan potensi Sumber Daya buatan di Kota Bandung menyatakan bahwa potensi alam, secara morfologis Kota Bandung terletak di tengah Cekungan Bandung, yaitu kawasan yang memiliki nilai strategis nasional. Kota Bandung juga termasuk dalam Daerah Pengaliran Sungai, sehingga mempunyai nilai penting karena merupakan pemasok utama waduk Saguling dan Cirata yang digunakan sebagai pembangkit listrik, pertanian, dan lainnya. Potensi SDM, diantaranya penduduk. Penduduk merupakan modal dasar keberhasilan pbm. Besaran, komposisi, dan distribusi penduduk akan mempengaruhi struktur ruang dan kegiatan sosial dan ekonomi masyarakat. Seluruh aspek pembangunan memiliki korelasi dan interaksi dengan kondisi 
kependudukan yang ada, sehingga informasi tentang demografis memilik posisi strategis dalam penentuan kebijakan.

$$
\text { Bagaimana pemahaman }
$$

tentang lingkungan fisik dan non fisik di Kota Bandung? Lingkungan fisik Kota Bandung yaitu lingkungan biotik adalah lingkungan yang menyangkut dengan alam. Lingkungan kerja fisik, yaitu semua keadaan yang berbentuk fisik yang terdapat disekitar tempat kerja yang dapat mempengaruhi pegawai dan kelembagaan baik secara langsung maupun tidak langsung. Lingkungan non fisik Kota Bandung, yaitu adalah lingkungan yang menyangkut dengan orang. contohnya sekolah, lingkungan keluarga. lingkungan kerja non fisik, yaitu semua keadaan yang terjadi yang berkaitan dengan hubungan kerja baik hubungan dengan atasan maupun hubungan sesama rekan kerja, ataupun hubungan dengan bawahan.

Lingkungan kerja yang baik dapat mendukung pelaksanaan kerja sehingga karyawan memiliki semangat bekerja dan meningkatkan kinerjanya.Bagaimana pemahaman tentang prioritas utama yang perlu dilakukan oleh lembaga? Prioritas utama dari Bagian Hukum dan Ham, yaitu pelayanan kepada pimpinan dan lembaga di lingkungan Pemerintah Kota Bandung, yaitu dalam pelayanan penyusunan Peraturan Daerah atau produk hukum daerah lainnya seperti Peraturan Walikota, Keputusan Walikota. Selain itu melayani bantuan hukum dalam penyelesaian sengketa baik perdata maupun tata usaha negara. Dalam arti Bagian Hukum dan HAM, berupaya melindungi aset daerah, dan kebijakan daerah.

Ketika ditanya di Dinas KUKM \& Perindag tentang bagaimana pemahaman pembangunan yang dilakukan selama ini? Pembangunan selama ini sudah sesuai dengan arahan yang tercantum dalam peraturan perundang-undangan berupa Rencana Jangka Panjang, Rencana Jangka Menengah, maupun Rencana Kerja Tahunan. Namun demikian hasilnya ada yang sudah maksimal namun juga ada yang belum. Begitu pula keterlibatan masyarakat nampaknya belum begitu optimal.

Bagaimana pemahaman tentang tahapan pembangunan? Tahapan pembangunan adalah hal yang tidak bisa tidak harus dilakukan, karena tidak mungkin pembangunan dilakukan tanpa tahapan. Tahapan pembangunan merupakan sesuatu yang harus dilakukan sesuai dengan ketentuan peraturan perundang-undangan yaitu tahapan pembangunan jangka panjang (20 tahunan), tahapan jangka menengah (5 tahunan), dan tahapan satu tahunan (rencana kerja pembangunan daerah).

Apakah selama ini ada evaluasi tentang pembangunan Kota Bandung? Evaluasi pembangunan kota merupakan sesuatu yang dilakukan baik oleh instansi pengawas internal seperti Inspektorat, dan DPRD maupun 
lembaga dari luar seperti BPK dan BPKP. Pemeriksaan dipandang sebagai suatu evaluasi sampai sejauh mana kesesuaian dengan anggaran yang ada, dan tujuan sasaran pembangunan. Evaluasi merupakan satu kesatuan dengan pengendalian, yang hasilnya dapat dijadikan bahan pula untuk penyusunan rencana pembangunan. Dengan demikian pelaksanaan evaluasi ini juga mengikuti tata caranya sebagaimana ketentuan Peraturan Daerah Nomor 07 Tahun 2008 tentang Tahapan, Tata Cara Penyusunan, Pengendalian dan Evaluasi Pelaksanaan Rencana Pembangunan Serta Musyawarah Pembangunan Daerah.

Bagaimana kinerja birokrat Pemerintah Kota Bandung dalam pelaksana tugas rutin sehari-hari? Secara umum kinerja birokrat Pemerintah Kota Bandung sudah sudah cukup baik, terlihat dari beberapa penghargaan yang diterima oleh Walikota dalam memimpin pemerintahan dan birokrasi di Kota Bandung.Kinerja demikian ditunjang dengan adanya keterbukaan dan tidak anti kritik, masyarakat diberikan peluang untuk melaporkan kinerja birokrasi.

Bagaimana pemahaman
tentang faktor-faktor yang
mendukung dan menghambat kinerja birokrasi? Seberapa jauh tingkat kemampuan pelaksanaan tugas-tugas organisasi dari suatu sistem yang telah ditentukan berdasar faktor situasional pada proses pelaksanaan dalam organisasi. Dengan demikian, maka penampilan sebuah organisasi dipengaruhi oleh dua faktor yaitu: faktor internal organisasi dan faktor eksternal yang berupa lingkungan. Kualifikasi dan kompetensi birokrat harus diakui masih cukup jauh dari harapan yang berdampak pada rendahnya kinerja pegawai. buruknya sistem. Upaya mereformasi birokrasi sering terhalang oleh sistem yang berlaku yang kurang mendukung perwujudan birokrasi ideal. Contohnya, sistem penggajian (remunerasi) belum maksimal untuk mendorong peningkatan kinerja. Antara pegawai yang berprestasi dan yang tidak atau antara yang berdisiplin dan yang bermalas-malasan memperoleh gaji dan perlakuan relatif sama.

Bagaimana dengan potensi Sumber Daya Alam (SDA), Sumber Daya Manusia (SDM), dan Sumber Daya Buatan di wilayah Kota Bandung ini? Banyak bahan mentah yang didatangkan dari luar Kota Bandung seperti dari Kabupaten Bandung, dari Garut, Cimahi, dan Sumedang. Sebenarnya Kota Bandung sendiri sudah menjadi kota jasa dan industri karena bahan mentah sudah tidak ada di sini. Kalau SDM termasuk unggul dibanding daerah lain, karena kampus-kampus bagus di Bandung ada Unpad, ITB, UPI, swasta juga banyak yang bagus. Berarti kalau SDM sebenarnya ada di sini. Hanya saja lulusannya banyak juga yang mengabdi di daerah bahkan negara lain. Potensi SDM bagus di sini, mencetak SDM bagus. Hanya saja tergantung mengabdi di mana, apakah di Bandung atau tidak. 
Kalau untuk SDM di dinas, jujur saja dari 103 orang yang betul-betul bisa kerja 20\%, $80 \%$ formalitas datang merokok pulang, termasuk pejabat yang banyak tidak bisa kerja, tidak hanya pelaksana yang tidak paham tupoksi. Termasuk Kabid di sini juga kurang kapabel. Di sini di bawah kepala dinas ada sekretaris, lalu ada 6 bidang: bidang kelembagaan, pengembangan usaha koperasi, perdagangan, industri formal, UKM, industri kecil pedagang kecil plus UPT Balai Latihan (UPT Balatkop, UPT Balai Industri). Sekarang sedang dirintis Balai metrologi untuk tahun 2016.

SDM seperti ini karena salah rekrut, yang berkualitas baru dari tahun 2006 ke sini, sebelum 2006 tidak kapabel. Orang-orang yang seperti itu tidak akan mau bicara seperti ini karena berbicara tentang dirinya sendiri. Bagaimana pemahaman Bapak tentang lingkungan wilayah kerja? Lingkungan fisik dan non fisik. Di sini tidak semua orang punya komputer, tidak semua orang bisa memakai komputer, tidak semua orang bisa menyalakan komputer, tidak semua orang bisa shut down komputer. Dari 103 perkiraan saya sekitar 40 orang bisa menyalakan dan mematikan, 30 yang bisa mengetik, 15 yang bisa buat PPT, dari 15 itu tidak seorang pun yang tahu bahasa pemrograman. Padahal sebenarnya kalau ada yang bisa pemrograman, kami tidak perlu belanja pihak ketiga supaya menghemat anggaran.
Iklim per bidang lebih eksklusif, individualis, kalau sekretariat tidak, karena mengayomi semua bidang. Kalau bidang mementingkan kepentingan masingmasing, kalau yang satu banyak tugas yang lain tidak mau membantu, kalau tidak diperintahkan kepala dinas tidak mau. Kalau sekretariat saling bantu.

Bagaimana pemahaman Bapak tentang prioritas utama yang perlu dilakukan oleh Dinas?

Pembenahan tata kelola organisasi. Pertama, hal ini karena tupoksi masih abstrak. Kepala dinas, sekertaris, kepala bidang, kepala seksi belum bisa menerjemahkan tupoksi itu ke dalam bentuk paket-paket pekerjaan yang siap dialokasikan ke bawahannya. Kedua, pejabat struktural ini tidak menguasai all section dari semua pekerjaan bawahannya. Artinya, karena tidak menguasai, dia mempunyai ketergantungan yang amat besar pada anak buah. Ketiga, fungsi training tidak berjalan. Jadi, ketimpangan kompetensi yang 80\% 20\% akan terus-menerus seperti itu. Ini akan berakhir nanti, setelah yang lamalama pensiun, yang baru masuk, berakhir secara alamiah. Apakah akan menunggu 2030 atau bisa lebih cepat. Untuk itu, kalau mau cepat harus dibenahi tata kelola organisasinya. Anak buah bukan tidak mau bekerja keras tapi tidak mau diperlakukan tidak adil, yang pintar jadi kebanyakan tugas tapi gaji sama dengan yang tidak kerja. Yang malas tambah malas, yang rajin jadi 
overload. Jadi yang banyak tugas cari pelampiasan, seperti S2 atau kalau perempuan hamil, kalau lakilaki pindah ke dinas lain. Kondisi ini perlu diketahui oleh orang ilmu pemerintahan. Bagaimana pembangunan KUKM \& perindag yang dilakukan selama ini? Indikator pembangunannya salah. Kita itu punya visi dan misi kota tertuang dalam RPJMD selama 5 tahun. RPJMD dikonkritkan dalam bentuk per tahun RKPD, Renstra tadi diterjemahkan ke dinas jadi Renstra dinas 5 tahun, per tahun kita buat dokumen turunan Renja, dalam renja setiap kegiatan punya indikator kegiatan. Misalnya, kegiatan bimtek indikatornya terselenggaranya bimtek. Terselenggara ya terselenggara, tapi kan bukan itu harusnya. Dampaknya seperti apa. Harusnya di indikator terselenggaranya bimtek IKM dengan misalkan, dengan dampak seperti ini. Misalnya, mereka bisa jual online lalu dipantau ada kenaikan omset tidak 3 bulan kemudian. Lalu, anggaran 100 juta sudah terserap 99\%. Sekarang ini indikatornya dangkal, yang dinilai serapan anggaran. Ini yang sedang diperbaiki untuk itu ada LKIP baru. Jadi, selama ini yang jago belanja ditepukin. Justru harusnya kalau ada 100 juta, yang memakai 50 juta tapi dengan manfaat yang sama dengan 100 juta. Jadi, mindset nya salah. Ilmu "kelirumologi".

Bagaimana sebaiknya tahapan pembangunan KUKM\&Perindag oleh Dinas dilakukan? Harusnya diprioritaskan SDM dahulu baru sarana dan prasarana. Misalnya, dalam perdagangan, revitalisasi pasar tradisional. Revitalisasi pasar tradisional harusnya kan orangnya dulu dicerdaskan baru revitalisasi sarana dan prasarana pasar, ditata kiosnya, persaingan sempurna, jangan sampai ada monopoli. Kita akui saja pasar kita liberal. Harus ada peran negara. Hadirnya itu, misalkan di kita melalui operasi pasar. Kalau di sini SDM dan sarana prasarana berjalan bersama. Namun, perencanaan tidak dibuat secara matang. Misalkan membuat Renstra, asal menerjemahkan dari RPJMD, jadi judul kegiatan sudah dikunci, dicocok-cocokkan dengan visi. Dibuat kegiatan dahulu baru dicocokkan dengan visi. Bukan kegiatan menyesuaikan visi, tapi visi menyesuaikan dengan kegiatan. Apakah selama ini ada evaluasi tentang pembangunan KUKM \& Perindag Kota oleh Dinas? Tidak ada yang mengevaluasi. Paling LKIP yang dibuat dari indikator dangkal tadi. Tidak ada yang menilai kinerja kami. Kami menilai laporan sendiri. Laporan kinerja kami dilaporkan. Dan mereka asal terima laporan saja. Serapan anggaran yang dilihat.

Berapa persen uang yang dibelanjakan, bukan tujuan yang tercapai, hanya pembangunan fisik yang dilihat. Kalau kinerja oleh orpad itu juga atas dasar indikator dangkal. Bagaimana kinerja birokrat/ pegawai Dinas KUKM \& Perindag 
dalam pelaksanaan tugas rutin seharihari? Tidak teralokasi secara merata. Misalkan, saya sebagai kasie, saya terjemahkan tupoksi, saya buat terjemahan dalam paket-paket pekerjaan, lalu dialokasikan pada empat anak buah. Kasie nya saja tidak paham tupoksi, anak buahnya punya kompetensi berbeda-beda. Jadi, siapa yang bisa mengerjakan jadi overload. Tapi kondisi ini seolah-olah tidak terselesaikan. Saya baru masuk 2009, begitu saya masuk, kok gini, karena di swasta tidak begini. Jam datang jam pulang tidak sesuai. Alat tidak berguna karena tidak ada sistem punishment dan reward. Yang tidak absen tidak apaapa, tidak ada sanksi. Ada yang datang hanya untuk apel lalu pulang.

Selanjutnya tentang apa saja faktor-faktor yang mendukung dan menghambat kinerja birokrasi? Jawabannya adalah masalah leadership yang kurang sekali. Komunikasi mulai membaik karena adanya whatsapp. Bagaiana caranya membangun teamwork? Caranya dengan character building untuk pembinaan aparatur, semangat kerja sudah sedikit ada perbaikan, walaupun sedikit tapi yang penting ada perubahan.

\section{d. Renewal.}

Menurut Gouillart dan Kelly (1995: 7), renewal deals with the people side of the transformation, and with the spirit of the company. It is about investing individuals with new skills and new purposes, thus allowing the company to regenerate itself (Renewal berurusan dengan sisi manusia dari transformasi, dan dengan semangat dari perusahaan. Renewal berkaitan dengan memberikan individu-individu kemampuan-kemampuan dan tujuantujuan baru, sehingga memungkinkan perusahaan untuk memperbarui dirinya sendiri). Berdasarkan pernyataan Gouillart dan Kelly ini adalah bahwa renewal itu berkaitan erat dengan masalah "spirit" atau semangat dari tiap individu dalam suatu organisasi.

Berdasarkan hasil wawancara dengan pertanyaan bagaimana pemahaman tentang semangat melakukan pembangunan yang telah dilaksanakan di bidang fisik, bidang sosial, dan bidang budaya, terungkap bahwa pembangunan yang dilakukan oleh Pemerintah Kota Bandung sudah mencakup ketiga bidang tersebut. Pembangunan di bidang fisik nampak dilakukan pada sektor infrastruktur kota seperti jalan dan trotoar, pembangunan perumahan bagi masyarakat seperti pembangunan rumah susun, dan sebagainya. Pembangunan di bidang sosial, nampak dilakukan pada sektor kesehatan, pendidikan, dan keagamaan. Begitu juga dengan pembangunan di bidang sosial, dilakukan misalnya dengan menggiatkan kehidupan kesenian tradisional, olahraga tradisional, peningkatan budaya lokal, dan sebagainya.

Terhadap masalah ini peneliti mendapat penguatan dari hasil wawancara dengan Wakil Ketua 
DPRD Kota Bandung bahwa pembangunan kota di bawah kepemimpinan walikota sekarang ada peningkatan khususnya dalam pembangunan taman kota.

Bagaimana pemahaman tentang orientasi lembaga, arah dan harapan dari lembaga yang ada di Kota Bandung? Orientasi lembaga yang ada di Kota Bandung sudah tepat dan sesuai untuk mencapai visi dan misi Kota Bandung, baik dalam bidang pembangunan, dan pencapaian kesejahteraan rakyat. Haparannya, agar kinerja dari lembaga yang ada senantiasa ditingkatkan supaya selalu mampu memberikan pelayanan terbaik bagi masyarakat Kota Bandung.

Apa sajakah aturan yang mesti diperbaharui dan perlu direvisi dalam rangka renewal ini? Menurut responden, tentu agar spirit ini terpelihara dengan baik maka peraturan-peraturan yang perlu diperbaiki/diperbaharui yaitu peraturan mengenai penggajian, dan peraturan yang mencakup kinerja pegawai serta kesejahteraannya.

Apakah SDM yang ada di lembaga sudah sesuai dengan kompetensinya. Secara umum untuk di Bagian Hukum dan HAM, SDM yang ada sudah cukup sesuai dengan kompetensinya yaitu para sarjana hukum dengan tambahan pendidikan dan latihan di bidang teknis legal drafting, dan bantuan hukum (kepengacaraan daerah), serta dokumentasi hukum.

Apakah sistem penggajian sudah sesuai dengan kinerjanya?
Sistem penggajian yang ada belum sesuai dengan kinerja dari pegawai. Pegawai yang kinerjanya kurang ataupun yang baik sekali gajinya sama. Apakah learning system yang berlaku saat ini sesuai dengan yang diharapkan? Sistem pembelajaran yang ada sudah cukup sesuai dengan yang diharapkan, mengingat adanya Monitoring dan Evaluasi, serta pendidikan dan latihan SDM untuk peningkatan kompetensi. Namun demikian, masih ada beberapa hal yang belum tercapai seperti pendidikan dan latihan untuk meningkatkan jumlah fungsional tertentu seperti diklatnya terasa kurang, dan tidak setiap tahun ada. Apakah Pemerintah Kota Bandung sudah melakukan inovasi? Pemerintah Kota Bandung telah melakukan inovasi, terbukti dengan adanya Program Inovasi Pembangunan Dan Pemberdayaan Kewilayahan.

Berdasarkan pertanyaan apa yang dilaksanakan oleh Dinas KUKM \& Perindag baik dari segi fisik, sosial atau budaya? Maka jawabannya yaitu kalau dari fisik dari segi kebutuhan masyarakat adanya UPT Balai Latihan Koperasi dan UKM dan Balai Latihan Industri. Kalau kantor Dinas, paling renovasi kantor. Sarana prasarana seperti hardware dan software. Tapi, untuk yang real dinikmati masyarakat adalah balai latihan karena ada transfer ilmu. Dinas memfasilitasi tenaga ahli untuk masyarakat. Dari sisi sosial, ada komunitas koperasi UKM, industri. Ada 30 sentra 
industri. Walaupun komunitas bukan buatan Dinas. Dinas membina mereka. Dari sisi budaya, kultur berjalan sendirinya. Apa yang Dinas lakukan, tercipta akibat, kebiasaan.

Kemudian tentang orientasi, arah, dan harapan dari Dinas, yaitu adanya Dinas KUKM \& Perindag yang sesuai dengan visi, harapan Dinasa adalah koperasi yang berdaya saing guna mewujudkan ekonomi yang kokoh dan berkeadilan. UKM yang berdaya saing, kompetitif, guna kontribusi pembangunan yang kokoh dan berkeadilan. Yang dagang juga sama. Menurut sajakah aturan yang berkaitan dengan pembangunan KUKM \& Perindag harus diperbaharui dan perlu direvisi? Mengapa? Sampai detik ini dari sisi aturan tidak terlalu ada permasalahan. Koperasi, UU koperasi, raperda waralaba blue print nya ada di sini, diterjemahkan dalam perwal waralaba, aturan-aturan yang ada selama ini secara kebutuhan sudah cukup. Aturan sudah ideal, sudah baik, hampir tidak ada yang cacat hukum, mengarah pada yang ideal. Namun, pelaksanaannya yang agak menyimpang.

Berhubungan dengan pertanyaan tentang SDM, apakah SDM yang ada di Dinas KUKM \& Perindag sudah sesuai dengan kompetensinya? Jawabannya masih terjadi kesenjangan kompetensi. 80\% datang ke kantor sekadar formalitas. $20 \%$ lagi setidaknya bisa bekerja.bagaimana dengan sistem penggajian apakah sudah sesuai dengan kinerja? Tidak. Gaji sama.
Yang beda TPP tergantung kemampuan daerah masing-masing.

Apakah learning system yang berlaku saat ini sudah sesuai dengan yang diharapkan? Dari sisi pembinaan aparatur, target saya mengubah mindset. Selama ini mindset PNS keliru. Seperti tadi, kita dikasih uang, yang dihitung bukannya habis berapa. Harusnya dengan habis sekian, dapat apa. Baru tahun ini ada upaya untuk pembinaan aparatur melalui pelatihan character building. Bagaimana inovasi-inovasi yang sudah dilakukan oleh Dinas ini? Kita sudah masuk smart office. Dinas menerjemahkan smart office dari konsep smart city ala Pak Ridwan Kamil. Yang tadinya Dinas bekerja manual. Smart aparatur; Smart infrastruktur; Smart sistem. Infrastruktur, dari gedung, Dinas sedang membuat suasana ruang kondusif untuk bekerja, bukan mengobrol. Lalu hardware seperti laptop, HP android. Kita media lewat whatsapp. Smart system yaitu tata kelola organisasi. Punishment and reward harus ada. Apakah reward dalam bentuk skors, honor, dikeluarkan, atau yang lainnya. Kita sedang cari regulasinya, ada tidak regulasi yang mengatur itu. Smart aparatur adalah mindset aparatur. Skill juga ada pelatihan bahasa Inggris, komputer, bimtek pajak untuk keuangan.

Berdasarkan uraian di atas bila ditinjau dari perubahan sistem hukumnya yang meliputi substansi, struktur dan terutama budaya hukumnya atau kesadaran hukumnya 
kurang simultan. Dari hasil wawancara renewal tengah terjadi di Pemerintah Kota Bandung namun membangun substansi hukum seperti spirit tentang smart system itu belum dilakukan. Bila substansinya belum ada tentu berpengaruh terhadap stuktur dan budayanya yang akan berjalan kurang sempurna. Meminjam ungkapan Gouilart dan Kelly, ..business transformation as the orchestrated redesign of the genetic architecture of the corporation.

\section{PENUTUP}

Berdasarkan uraian di atas dapat disimpulkan bahwa di Kota Bandung pasca pergantian walikota tahun 2013 telah terjadi adanya reframing namun tidak disertai restructuring. Dalam hal revitalization dan renewal ada sedikit dilakukan namun tidak dibarengi dengan perubahan regulasi yang memadai contohnya tentang konsep Bandung Juara yang merupakan suatu renewal dalam menyemangati aparat untuk giat meraih prestasi dalam berbagai bidang sehingga menjadikan Bandung juara (kahiji). Sebaiknya dibarengi dengan memberikan landasan hukum formal setingkat Perda dan didukung kekuatan politik di lembaga DPRD Kota. Hal inilah yang terungkap di DPRD yang menunggu pihak Pemerintah Kota untuk merapat ke DPRD membicarakan langkah konkrit dalam mewujudkan reframing baru di Kota Bandung.
Transformasi manajemen pemerintahan Kota Bandung ini bila dikaitkan dengan pemikiran Lawrence M. Friedman (2009: 17), yang menyatakan bahwa suatu sistem hukum dalam operasi aktualnya merupakan sebuah organisme kompleks di mana struktur, substansi, dan kultur berinteraksi. Kemudian untuk mewujudkan "kepastian hukum" dalam suatu sistem pemerintahan yang berlandaskan hukum, paling tidak haruslah didukung oleh unsur-unsur sebagai berikut, yakni: (1) substansi hukum, (2) struktur hukum, dan (3) budaya hukum. Friedman mengatakan bahwa tegaknya peraturan-peraturan hukum akan sangat bergantung kepada "budaya hukum" masyarakatnya. Budaya hukum masyarakat tergantung kepada budaya hukum anggotaanggotanya yang dipengaruhi oleh latar belakang pendidikan, lingkungan, budaya, posisi atau kedudukan, bahkan kepentingankepentingan.

Dengan demikian di Kota Bandung yang perlu ditingkatkan adalah menyangkut ketiga hal yang disebutkan Friedman di atas yaitu substansi hukum berupa membuat regulasi-regulasi yang mewadahi reframing yang dilakukan Walikota Ridwan Kamil agar setiap kebijakan yang diambilnya seperti konsep Bandung Juara memiliki legitimasi kuat secara legal. Demikian pula struktur hukum dan budaya hukum perlu untuk dipikirkan sebagai sarana mewujudkan kebijakan-kebijakan 
yang telah dan akan diimplementasikan.

Kebijakan publik umumnya harus dilegalisasikan dalam bentuk hukum, karena pada dasarnya sebuah hukum adalah hasil dari kebijakan publik (Muchsin dan Fadilah Putra : 2015, 37). Bahwa sesungguhnya antara hukum dan kebijakan publik itu pada tataran praktek tidak dapat dipisah-pisahkan. Keduanya berjalan seiring sejalan dengan prinsip saling mengisi. Menurut Bambang Sunggono, hukum akan memberikan legitimasi bagi kebijakan (law effectively legitimates policy) dan kebijakan dapat dipaksakan berlakunya (pelaksanaannya) dan bersifat mengikat bagi orang-orang atau pihak-pihak yang menjadi sasaran kebijakan (Bambang Sunggono, 1994 : 53).

Dengan demikian masih relevan hasil temuan Samugyo Ibnu Redjo yang meneliti transformasi manajemen di Kota Bandung bahwa transformasi manajemen pemerintahan daerah bukan hanya membutuhkan political will dari pemerintah melainkan juga membutuhkan keinginan berubah dari anggota manajemen pemerintah pusat maupun daerah. Oleh sebab itu, sebaiknya setiap kebijakan pengaturan yang dikeluarkan oleh Sunggono, Bambang, 1994, Hukum dan Kebijaksanaan Publik, Jakarta: Sinar Grafika.
Pusat seyogyanya diikitu pula dengan strategi lanjutan mengenai pengamanan pelaksanaanya di daerah (2012: 211).

\section{DAFTAR PUSTAKA}

Friedman, Lawrence M. 2009. Sistem Hukum, Perspektif Ilmu Sosial, diterjemahkan dari Buku The Legal System: A Social Science Perspective, New York: Russell Sage Foundation. 1975, oleh M. Khozim, diterbitkan oleh Penerbit Nusa Media, Ujungberung Bandung.

Gouillart, Francis J. dan James N. Kelly. 1995. Transforming the Organization. New York: McGraw-Hill Inc.

Muchsin dan Fadilah Putra, 2015, Hukum dan Kebijakan Publik. Surabaya : Universitas Sunan Giri dan Averoes Press.

Ibnu Redjo, Samugyo, 2012, Transformasi Manajemen Pemerintahan, Bandung : Asosiasi Ilmu Politik Indonesia (AIPI).

Soekanto, Soerjono dan Sri Mamudji, 1995, Penelitian Hukum Normatif Suatu Tinjauan Singkat,Jakarta: Raja Grafindo Persada. 